\title{
The Music Industry on (the) Line? Surviving Music Piracy in a Digital Era
}

\author{
Jelle Janssens, Stijn Van Daele and Tom Vander Beken \\ Institute for International Research on Criminal Policy (IRCP), \\ Ghent University, Belgium \\ European Journal of Crime, \\ Criminal Law and Criminal Justice 17 (2009) 77-96
}

\section{Introduction}

After successive years of growth during the 1990s, decreasing compact disc (CD) sales have been plaguing the music industry since 2000. Although several reasons have been cited to explain the decline in sales, the music industry mainly puts the blame on physical and digital piracy, more specific on $\mathrm{CD}$ and Internet piracy [1].

Piracy is not a new phenomenon. In the last decades, technological developments have allowed the music industry to discover and promote new music formats, but have also enabled commercially-minded pirates and private citizens to pirate music on a larger scale. Piracy was a minor problem for the music industry until the arrival of the compact tape cassette in the late 1960s and the wide-spread availability of home cassette recorders in the 1970s [2]. The advent of the CD in 1982 heralded a new era. Although this format boosted global music sales, the technology enabled master-quality copying in large quantities. Firstly, the development of encoding formats such as MP3 allowed users to easily transfer music to computers, transmit it via the Internet or decode the digitally recorded music for recording onto CDRs [3]. Secondly, when the switch was made from cassettes to CDs, most computers had limited storage capacity and were not always equipped with a sound card or external speakers. During the last decade, however, personal computers have become much faster and more powerful and most of them nowadays come with CD-ripping software and CDburners. Contemporary pirates are now able to create perfect, quasi-identical copies.

The possibilities offered by the new technologies did not go unnoticed. Whereas the music industry always had some sort of monopoly over the distribution of music to customers, they soon met with competition from entrepreneurs making the most of their chances to get a piece of the pie. Besides concerns about private citizens copying CDs onto CD-Rs, the music industry was - and still is - gravely concerned about full scale commercial music piracy. It did not take long for them to link full scale commercial piracy to organized crime [4]. Organized criminals would use CD revenues to finance other activities such as trafficking drugs, humans or weapons [5]. In combating organized crime, the music industry has found an ally in public and law enforcement authorities. They too, link - to some extent $\mathrm{CD}$ piracy to organized crime [6]. In several criminal cases, links have indeed been established between criminal organizations and $C D$ piracy and counterfeit products in general [7].

Music industry's monopoly position being shattered, consumers are now able to shop around. It is not, however, physical piracy that has received a lot of attention recently, but digital piracy (due the rise of the Internet and the plummeted costs of personal computers) which is seen as one of the biggest threats to the music industry today. Although Internet piracy can take many forms, one variant, file sharing through peer-to-peer (P2P) networks, is said to have a devastating impact on global $\mathrm{CD}$ sales [8]. The very idea behind these 
networks is to allow users to share music files with others for free. With the global widespread of the personal computer (PC)[9], the increasing pervasiveness of the Internet and broadband connections[10], and the emergence of digital compression technologies, this type of piracy can indeed assume vast proportions.

New technologies provide both opportunities as well as challenges. This article discusses opportunities to tackle organized crime involvement in music piracy and opportunities for the music industry to survive in the digital era. In a first part, the piracy problem facing the contemporary music industry is examined. In this context, the music industry is scanned for its own vulnerabilities and on the involvement of organized music pirates. In a second part, the future for the music industry and organized music pirates in the digital era is examined. Finally, options for the music industry in dealing with piracy in the digital era are proposed. The ideas and findings presented in this article apply only to those countries and regions where Internet pervasiveness is high. If there is no access to the Internet, there is no digital piracy.

\section{The music industry and piracy}

According to the International Federation of the Phonographic Industry (IFPI), CD sales have been falling continuously (except for a status quo in 2004) from 2,5 billion units in 2000 to 1,8 billion in 2006 (see figure 1). This decline is without doubt hurting the music industry since CD sales still account for a crucial part of the recorded music sales. From 1999 till 2002, global sales dropped 19.8 percent (from US\$38,6 billion to US\$30,9 billion). While the industry was doing better in $2003(+3.3 \%)$ and $2004(+4.7 \%)$, global sales dropped again in 2005 (-0.5 percent) and in 2006 (-4.9 percent) (see figure 2) [11].

Figure 1: Global CD sales in million units

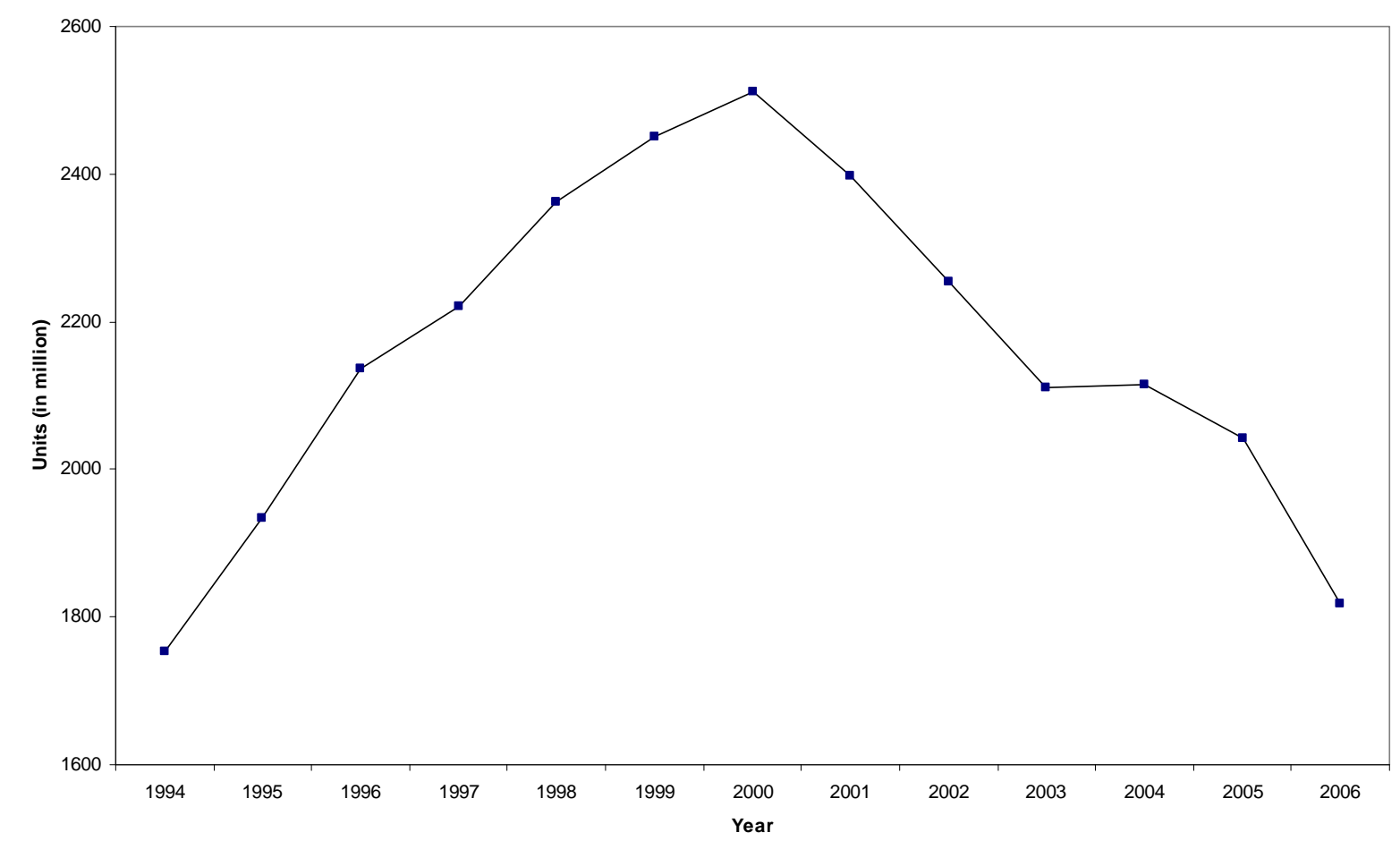

Source: IFPI, 2004 and IFPI “The recording Industry" 2000-2007:

http://www.ifpi.co.uk/content/section_statistics/index.html. 
The reasons cited for the disappointing results are numerous. Some simply blame the economy; others point the finger at major labels' practices, including price-fixing by the Big Five[12] making consumers pay too much for their CDs [13]. From 1999 to 2001, the average price of a CD rose 7.2 percent from US $\$ 13.04$ to US $\$ 14.19$. Simultaneously, new album releases went down as well, making it rather difficult to procure similar revenues to the year before [14]. Oberholzer-Gee and Strumpf also point towards an evolution in how music is distributed (from record stores to discount retailers), the ending of a period of high sales when consumers replaced older music formats with CDs, and the growing competition from video games and DVDs [15].

Figure 2: Global music sales in millions US\$ (IFPI, 2004)

Local currency values are converted to dollars at the exchange rate of each year.

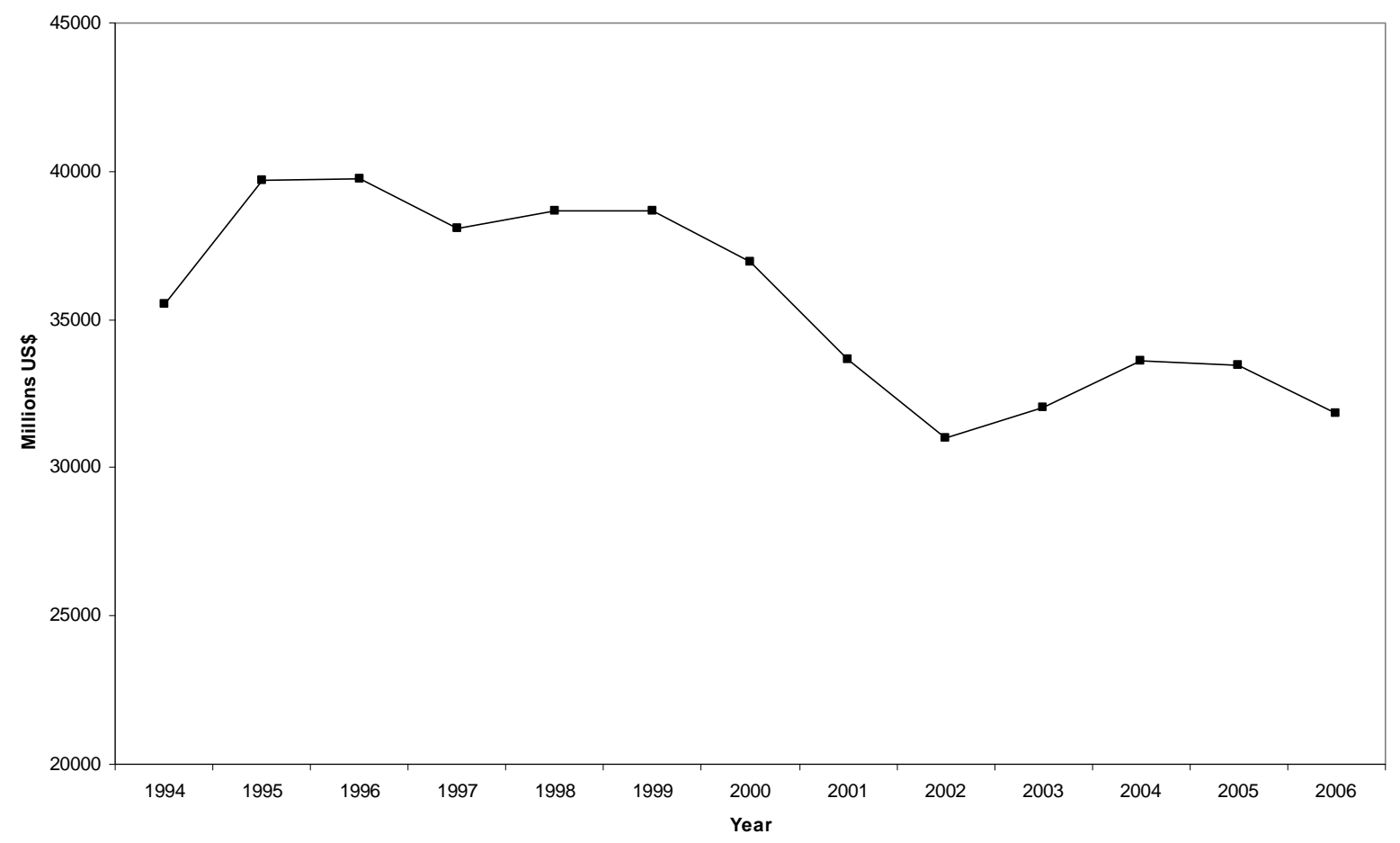

According to the music industry, however, physical and digital music piracy is the very culprit for the decline in CD sales. Each year, the IFPI releases a figure indicating the global value of pirated music. In 2005, the IFPI estimated the value of the global traffic of pirate products at US $\$ 4.5$ billion [16]. It equals out at about 13.5 percent of the total amount of global legitimate music sales. Not included in this figure, however, is file sharing over peerto-peer (P2P) networks, which is said to be responsible for a fall in global music sales of 22 percent between 1999 and 2004 [17]. The IFPI distinguishes CD-R piracy, pressed CD piracy, cassette piracy, Internet piracy and new forms of digital piracy such as LAN file sharing, digital stream ripping and mobile piracy. Internet and CD piracy are reported to have the biggest impact on legitimate CD sales [18].

\subsection{Internet Piracy}

Internet piracy can take many forms. It can involve making available databases of music files on websites or File Transfer Protocol (FTP) sites, up- and downloading files via Internet newsgroups or sharing files via peer-to-peer (P2P) networks. According to the music industry, there is a causal relationship between the growth of P2P networks and the decline 
of CD sales [19]. Liebowitz estimates that between 2000 and 2003 online file sharing reduced $\mathrm{CD}$ sales by as much as 30 percent, or about $\$ 4$ billion annually [20]. A lot of research has been conducted into the effects of Internet piracy on CD sales. The outcome of this research is not unambiguous. Some studies found that file sharing had no or little impact on music sales [21]. In a recent study, Andersen and Frenz found that P2P file-sharing tends to increase rather than decrease music purchasing [22]. Still there are many others who confirm the impact of file sharing on the music sales decline [23]. Others argue that a causal relationship is quasi-impossible to ascertain and piracy figures are often used for their rhetorical impact [24].

According to the data in figure 1 and 2, presented by the music industry, the year 1999 can be considered as a turning point. Although in figure 1 the decline starts in the year 2000 (due to regional dissimilarities), global sales (figure 2) started to drop in 1999. It is in that same year that Shawn Fenning started Napster, a type of P2P network, which would eventually attract as many as 70 million registered users [25]. While other factors (such as the economic climate for example) undoubtedly will influence global music sales, based on the data presented in figure 1 and 2, music industry's claim that P2P file sharing is at least partially responsible for the decline in $\mathrm{CD}$ sales seems legitimate.

\subsection{Piracy}

The amount of attention given to physical piracy, such as CD piracy, in literature does not quite correspond to the significance of the problem. All the indications are that the scale of the pirate business is considerable. It is thought that more than one in three of all music discs purchased around the world is an illegal copy. In 2005, the global value of traffic of pirate music products was estimated at US $\$ 4.5$ billion. 1.2 billion pirate CDs would have been sold worldwide in that same year [26]. Because the prices for pirated discs are used and not the legal prices, the full economic loss to the music industry is not measured [27].

Figure 3: The evolution in legitimate music $C D$ sales and pirate music $C D$ sales

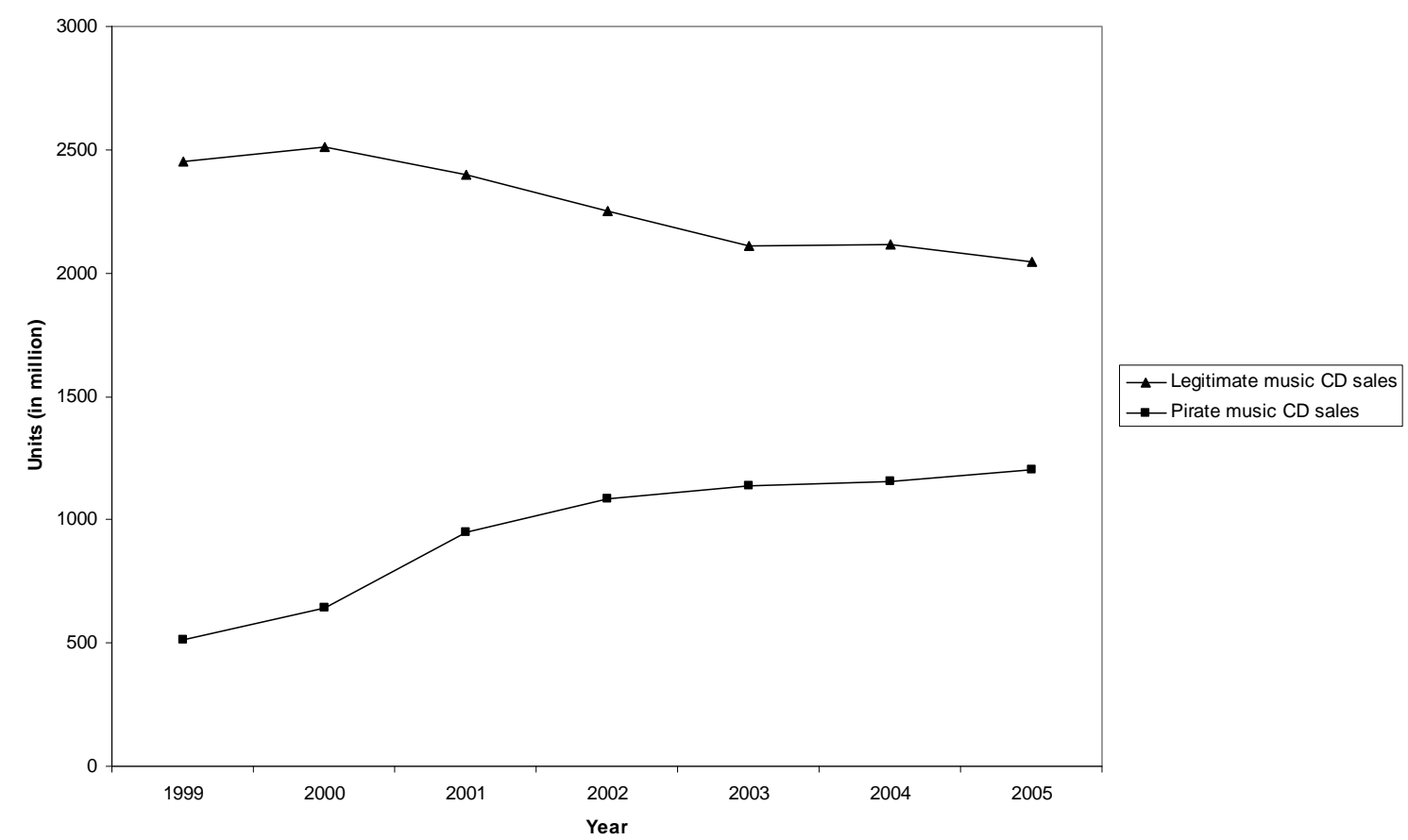

Source: IFPI, 2004; IFPI "The recording Industry" 2000-2007 and IFPI piracy reports 2000-2006: http://www.ifpi.co.uk/content/section_statistics/index.html. 
Figure 3 shows the evolution in both legitimate music $C D$ sales and pirate music CD sales. The latter category constitutes pressed pirate CDs as well as pirate CD-Recordable discs (CD-Rs). While the total amount of legitimate music CD sales is reasonably wellknown, figures relating to pirate music $C D$ sales are merely estimates and based on the number of seizures which provides information rather on law enforcement activities. Nevertheless, the figures in figure 3 show that in the year 2000 pirate CD sales rose sharply and have followed an upward trend since 2001. It is remarkable that both curves more or less mirror each other: when legitimate $C D$ sales drop, pirate $C D$ sales rise. Even when the figures of pirate music CD sales are an underestimate, this would theoretically not change the global trend that is set.

\section{Organized crime involvement in music piracy}

The threats to the music industry are well-known: both CD piracy as Internet piracy threaten music industry's most essential product, the compact disc. Of all music sales in 2004, CD sales accounted for 86 percent [28]. An extra dimension can be added to those threats: the involvement of organized crime in music piracy.

Organized crime is best described as a profit-driven illicit shadow economy. This is also reflected in the definition used by the UK National Criminal Intelligence Service and adapted by the music industry for the purpose of examining organized crime involvement in music piracy: "Organized crime constitutes any enterprise, or group of persons, engaged in continuing illegal activities which has as its primary purpose the generation of profits, irrespective of national boundaries" [29]. Although this definition does not cover all aspects of organized crime (the EU definition of organized crime defines eleven characteristics[30]) it is of use for this article. The reason why organized criminals would get involved in the music business is simple: just like all entrepreneurs they strive to maximize their profits. When organized music pirates have the same production technology at their disposal as the music industry, they become fearsome competitors. Their marginal costs will be the same, but not their average total cost function because they do not bear the fixed costs associated with developing the CDs [31]. In that way, organized music pirates' production costs will be less than those of the music industry providing them with a competitive advantage.

Legal and illegal activities do not always operate on distinct levels but are often connected and interdependent [32]. Moreover, legal and illegal organizations would strive to maximize economic and political advantages and try to minimize the risk of arrest and conviction [33]. Within the global music market, organized music pirates have found and exploited a thriving segment: the segment of people who are not willing to pay the price demanded by the music industry. To analyze the involvement of organized criminals in the music business and to understand why they are involved, it is necessary to look beyond their characteristics and activities and look to the markets in which they operate [34].

\subsection{Scanning for vulnerabilities in the music industry}

Since criminal or deviant behaviour takes place in a certain context [35], it is crucial to scan it for vulnerabilities. Methods have been developed (e.g., Method for Assessment of Vulnerability of Sectors (MAVUS) [36]) to scan for context-specific opportunities which could be exploited by criminals. The vulnerabilities of an organisation, sector or industry facilitate crime or irregularities and are found in the music industry as well [37]. 
An industry can be looked at from different perspectives. An important first perspective in the vulnerability approach is the economic perspective scrutinizing the entire production chain. To recognize the vulnerabilities of an industry, an understanding of the nature of the product is imperative. In the case of the music industry the actual product is not the CD, but the intellectual property which is in fact an intangible good [38]. In case of CD distribution, the intellectual property is linked to a certain carrier, i.e. the CD. The link to a carrier is important since copying a song is only punishable if the song is copied onto a different carrier. The fact that the actual product is an intangible good, combined with the relative ease with which CDs are now copied (as discussed above), music industry's product can be considered as highly vulnerable for criminal activity. Furthermore, CDs can be shipped very easily and do not require specific conservation methods, so they can be shipped together with other illegal goods [39].

Not only the product, but also the environment may well lead to crime. Since every sector is subjected to (governmental) regulations, the level of implementation and enforcement of these regulations determine the pervasiveness of criminal activities. Some countries, like Russia for example where CD manufacturing plants are not (effectively) combated [40], still lack proper legislation and are thus creating safe havens for criminals to produce counterfeit CDs [41]. In the past, legislation and enforcement in many countries was not that strong. Music industry's lobbying, increased media attention and global awareness of music piracy caused various regions to improve their fight against the phenomenon. In Europe, the 1998 Green Paper on Combating Piracy indicated a first commencement in this perspective [42].

Besides the product and the environment, pricing issues play an important role in piracy. Because of customers' increased mobility and to avoid "white van smuggling", record companies try to maintain a worldwide uniform price, so there is no use in shopping abroad. Yet, in countries where the average wages are about the equivalent of US\$70-100, most people cannot afford to pay US\$15 for a music CD [43]. CD piracy provides to some extent an answer to this discrepancy. This is reflected in the value of the pirate market as well. Although the number of pirated CDs is said to be up to 35 percent, its value only corresponds with a market share of 15 percent [44]. This implies that the pirated CDs cost less than half the price of their legal counterparts. In this perspective, pricing strategies need to take the efficiency of the black market into account [45].

Finally, although technological developments have offered opportunities to the music industry, they also have brought new challenges. First of all, the ease with which one nowadays can copy CDs adds to the vulnerabilities of the music industry. Although the equipment for $\mathrm{CD}$ manufacturing plants is more expensive and less mobile compared to that of home-made copying, low risks of being caught and weak deterrents make the investment worthwhile [46].

\subsection{The future of organized crime in music piracy}

Whereas the music industry used to have control over their product, technological developments have offered new opportunities to music pirates. Given the vulnerabilities of the industry: low (law) enforcement in some countries, the ease by which copies can be made, the fact that legal CD are not affordable in some countries, etc., several windows of opportunity are left open for organized crime networks.

The involvement of organized crime in music piracy has particularly been linked to physical piracy, more specific CD piracy. The $\mathrm{CD}$ as a product is therefore as important for organized criminals as for the legal music industry. Since the rise of Internet piracy is hurting the legal music industry, it also must hurt illegal CD sales. Figure 4 presents the evolution of 
physical piracy by format. In 2000 and 2001, the percentage of CD-Rs has increased with more than 10 percent, but the percentage of cassettes has declined with nearly the same proportion. Since the introduction of the $\mathrm{CD}$, tape cassettes have gradually lost their market share. Commercially-oriented pirates and private citizens have lost interest in tape cassettes as principal music format. The proportion of pirated CDs (no CD-R) was nearly stable [47].

Figure 4: The evolution of physical piracy by format

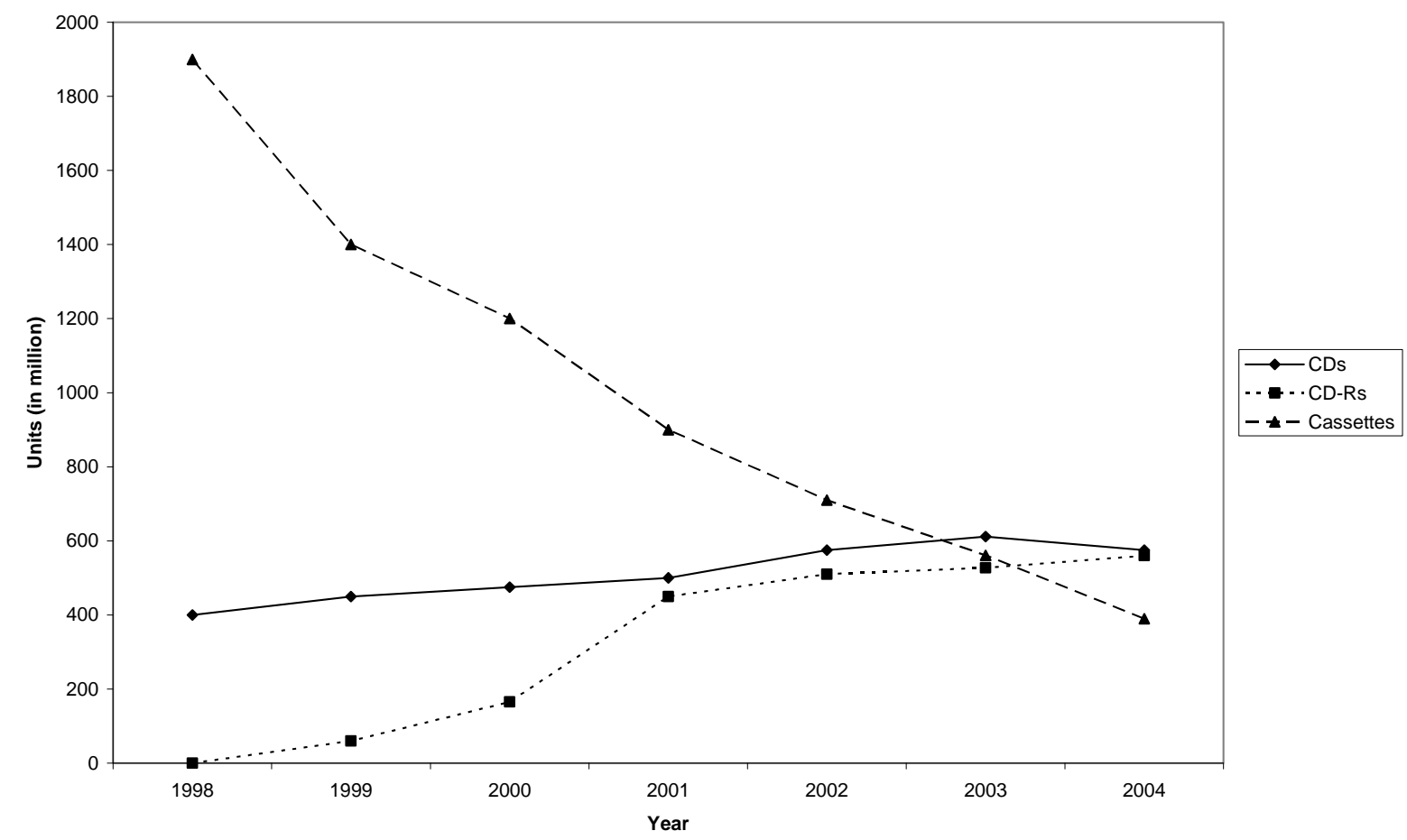

Source: IFPI, The recording industry, commercial piracy report 2003, 2004, 2005: http://www.ifpi.org/content/section_statistics/index.html

The discrepancy between the volume of pirate cassettes sold in 1998 and the volume of pirate CDs and CD-Rs is however remarkable. Whereas 1,900 million pirate cassettes were sold in 1998, both pirate CDs as well as CD-Rs have trouble to cross the border of 600 million units. One would well expect that the CD-R would partially replace the function of the tape cassette and as such obtain higher sales figures. Although the rise of CD-Rs in 2001 is notable, it is clear that the CD-R does not come near to the volume of pirate cassettes. Even though the CD has dethroned the tape cassette, the volume of physical piracy, in terms of million of units, has decreased over the last decade. There are three aspects that have to be considered in this perspective. First, the rise of CD-Rs can be accounted for by the decline in cassette piracy, as the CD is taking over tapes. Secondly, piracy rates can only be measured by the number of seizures. Hence, they tell at least as much about the activity of enforcement agencies as they tell about actual crime prevalence. Third, in 1999 Napster came along. Perhaps the limited growth of physical piracy from 2001 on may point towards a change in consumers' behaviour. If Internet is available, why buy (pirated) CDs when you can get your favourite music for free? In some countries, like Taiwan and Korea, Internet piracy has, according to IFPI, replaced not only legitimate businesses but also physical piracy [48]. Indeed, through file sharing the customer can not only listen to music freely, he or she can download it free of charge. In that way file sharing could also endanger the survival of physical pirates. A testimony: 
... According to Tony, the first 2 hours of every Saturday and Sunday morning at the local flea market always proved the most exciting. "We'd take 60 cases of CDRs down in the van and as soon as we got there a crowd would swarm around us. We had no competition and it was obvious the punters had no other suppliers. Inside 30 minutes, 90\% of the stock would be gone with some customers taking 2 or 3 cases each, presumably to sell on. After 3 hours we were cleared out and on our way home, always with huge amounts of money."

By 2001, Tony was renting a factory unit and employing 3 people to operate duplicators 24 hours a day, 7 days a week but although business was lively right up to 2004, profits were being squeezed every year. Forced to increase the amount of media burnt each week to make up for the shortfall in profit, it became clear that the business was in trouble - demand was falling dramatically.....

... Tony is very clear about why his rags to riches story has gone back to rags again. "File-sharing, P2P - call it what you like. When you asked a customer why he wasn't buying anything, 9 times out of 10 it was 'BitTorrent this, LimeWire that'. Add that to the fact that huge numbers of PC users have burners and fast broadband and its obvious why I had to get out and earn a living another way. We had it good for a while but I don't think those days are coming back." [49]

Organized music pirates have sponged on the achievements of the music industry. While the industry was investing in new talent, organized music pirates took advantage of their successes. When an artist was doing well, the demand for CDs of that particular artist rose. That is when organized music pirates came on the scene by offering low-priced pirated CDs of that same artist. When those CDs no longer sell, they are confronted with a huge problem. The question is whether they will share Tony's fate, or whether they will be able to alter their "business plan".

\section{The music business goes digital}

The Internet did not play a major role in the distribution of music until the spread of the MP3 [50]. The success of this format is not only due to the absence of security features, making it extremely appealing to consumers as they do not encounter restrictions on the use of the content, but most of all, it compresses audio files with little loss in quality [51]. The application of this technology is extremely popular among file sharers. MP3 technology enables users to compress music files in easily transferable data. Whereas a three minute track on a CD would use for example 30 to 40 Megabytes $(\mathrm{Mb})$, the same track, converted into a MP3 files would use merely $3 \mathrm{Mb}$. This has of course, irrespective of the bandwidth, consequences for the speediness of transferring music files through the Internet.

The advent of Napster in 1999 ignited P2P file sharing [52] and in its two years of existence, Napster has changed the music business and its relationship with consumers. As a reaction to the growing threat of file sharing, the music industry responded in two ways. First it tried to dissuade people to get involved in P2P file sharing by setting up awareness campaigns. Secondly, it tried to scare people off by threatening with legal actions. Essentially three types of legal actions have been engaged by the music industry: against file sharing platforms, against Internet service providers (to reveal user's identities or to pay damages for the infringement or block illegal sites), and against individual P2P users [53]. The people being sued by the music industry range from college students, laboratory assistants to parsons [54]. The results of these actions are ambiguous and have not done the image of the music industry any good. Today there are much more P2P services than there were in the time of Napster and they are more difficult to be shut down. Progress in technology, the growth of consumer broadband and cheap data storage makes it impossible to prevent this type of activity [55]. Napster operated a central server that indexed its users and song titles 
[56]. Contemporary P2P services do not longer rely on a central indexing server. By downloading the necessary software onto the user's computer, the network would still function even if the company that provided the software would cease to exist. Therefore, some say that file sharing should be made legal and new ways to compensate copyright holders developed and implemented [57].

File sharing can have three possible effects on the music industry. The one the industry is focusing on the most, is the substitution effect. If consumers are able to download entire CDs through the Internet for free, they would no longer be willing to buy a CD legally. This vision is however strongly contested since it is unlikely that each download would displace a market sale [58]. Van Wijk correctly argues that people, who would download a free copy, would not necessarily buy the same product at a legal market price. Another effect of file sharing is the sampling or exposure effect. Through file sharing, people can experience the product thoroughly before making a purchase decision [59]. The traditional way of the music industry to inform consumers of new products is to spend large costs on advertising and promotion. The Internet can increase both demand and consumption for it enables users to discover and acquire new music and artists quicker, easier and more flexible [60]. This positive effect on music sales is confirmed by recent research [61]. A third potential impact of file sharing is the network effect which can be more or less compared with the effect of radio play [62].

Understanding that consumers had to have legal alternatives, and the evolution of online distribution of music had become insurmountable, the music industry decided to go online. In December 2001, MusicNet was setup by three major labels, Warner, EMI and BMG. Sony and Universal soon followed with PressPlay [63]. Subscription-based, the number of users was rather disappointing. First of all, the choice of music was rather limited since the labels merely offered a selection of their libraries. Secondly, the Big Five were concerned that their downloaded music would be easily copied and distributed. Therefore technological restrictions were put in place. Customers found themselves restricted by, for example, the period of time a download could be kept, the numbers of copies that could be made etc. These limitations did not provide the music industry a competitive advantage vis-à-vis file sharing where such restrictions are absent.

It was not until the advent of Apple Corporation's iTunes in 2003 that the music industry broke through in the online music distribution. Apple met the shortcomings and offered customers access to a larger music catalogue and for the price of US $\$ 0.99$ one could purchase a song with few restrictions on the use of it. In 2004 the IFPI began publishing online music reports [64]. Downloaded digital single tracks climbed from 160 million units in 2004 to 795 million units with revenue of US\$397 million in 2004 and US\$2000 million in 2006. Although the transition to online distribution of music has had its difficulties, it is now relatively successful. However, it does not look like digital music sales will be able to compensate for the decline in $\mathrm{CD}$ sales in the near future. The challenge now is for the music industry to try to compete effectively with $\mathrm{P} 2 \mathrm{P}$ networks and promote themselves in a new (digital) environment [65].

\subsection{Online music distribution: the choice between a legal and illegal purchase}

In the presence of the threats facing the music business, the industry had to alter their business plan. One of the adaptations to the new (digital) environment is distributing music online. Although digital sales are doing relatively well, they have a long way to go before they can replace CD revenues (if at all). Nevertheless, the industry has opened up a new (thriving) market: they run online music stores, provide music for digital music players and 
ring tones, cut deals with the mobile phone industry etc. Are organized music pirates able to do the same?

It would be naïve to think organized criminals are not able to sell music through the Internet as well. It is well known that criminals (individually as well as organized) are perfectly able to adapt to changes in the environment [66]. They too are perfectly capable to set up online music stores and provide customers with for example ring tones. They will, however, have to put in a great effort to stay as invisible as possible for law enforcement agencies for although criminals are resourceful, transactions through the Internet leave traces behind. Furthermore, the ICT-knowledge of enforcement agencies does not stay behind either. Besides concerns about detection, organized criminals may very well consider if the effort is worth it. Why would people be willing to purchase music online illegally if there is a legal alternative? Price differentiations will no longer be as significant as before since the production costs of CDs are now irrelevant. Moreover, how could illegal online music stores add value to their product in the presence of file sharing and still be able to compete with legal online music stores?

To analyze the online music business an economic approach is less valuable since it is not bound to a static carrier. A rational choice perspective, however, provides information on the choices customers have to make during their purchase decision. First of all, in making the decision whether or not to purchase music legally or illegally, the prime cost plays an important role [67]. Secondly, since the customer wants value for his money, the quality and the perceived quality of the product is at least as important [68]. There is also an ethical value involved: not everyone is keen on purchasing a product illegally [69]. Besides the risk of inferior quality (there are no guarantees with illegally obtained music), there is a risk of receiving digital malware. Music will be bought legally when the price is worth the differences in ethical consideration, (expected) quality and (perceived) risks. As ethical beliefs of consumers are independent variables, it is for legal providers important to combine high quality with competitive pricing and minimal risks [70].

Should consumers nevertheless opt for purchasing music through organized crime networks, ethical beliefs are no longer relevant. The risk of receiving malware and encountering legal actions makes it, on the other hand, more likely that people will only buy and download music legally if the high quality and low risks compensate for the higher price. The internet and its embedded risks may therefore very well reduce the profit margins of organized criminals.

Moreover, in the presence of P2P and other networks, digital music will only be purchased illegally when compared to file sharing the quality of the music is higher or the risks are lower. There is no reason to believe that the music files purchasable in illegal online music stores would be of a higher quality than those downloadable through file sharing networks as the quality of MP3 files is perceived as close to that of an original CD [71]. When organized music pirates would want to alter their business plan in accordance with the music industry and distribute music online, chances are they will not manage to keep afloat. There are of course other ways to make money on the Internet. (Organized) criminals could embrace the file sharing technology and offer music free of charge to users on their network. Although they would not receive money for the music distributed that way, they could attract advertisers and allow them to advertise on their website (providing they pay up of course). As they would openly manifest themselves in such manner, they would become more vulnerable to legal actions. 


\section{Implications for action}

For the music industry, buying music should be made easier than stealing music [72]. With the increasing pervasiveness of the Internet, this challenge is bigger than ever. The music industry has to realize that the "golden years" are over and that they, in order to avoid a complete downfall, have to adjust and alter their business plan. The traditional (physical) music industry is highly vulnerable to piracy and organized crime activities, urging the need to switch to a less vulnerable business model. The initiative to distribute music online has been relatively successful and should be encouraged for online music distribution not only changes the distribution chain; it also has a positive impact on expenses: lower coordination costs, lower physical distribution costs and the possibility for redistribution of the total profits [73]. Moreover, because the Internet offers more opportunities to meet customers' demands, possible profits for organized criminals are likely to decrease, which by consequence turns the Internet into a less interesting medium from their perspective.

The music industry could also take a rather permissive stance to piracy as several effects of file sharing influence the music business positively. Free provision of digital music reduces opportunities for organized crime groups to get involved in online piracy. Criminal organizations cannot compete with file sharing networks for although file sharing is illegal, it is not profit-driven. When it comes to the price of the product, the legal industry cannot compete with file sharing networks either. They therefore have to bear in mind that the choice between legal or illegal downloads not only depends on the financial cost of the product, but that ethical considerations, quality and risk perception are also important. Consequently it is imperative to make progress in these areas. Quality improvement is hard to achieve and could as well be transferred to the illegal market. Concerning ethical values, encouraging steps have been made by IFPI's educational project "Young people, music and the internet" (accompanied by the website www.pro-music.org) to explain the specifics behind online music in general and file sharing in particular [74]. Legal action could serve as a last resort but has more an influence on the risk perception than it has on ethical beliefs and it would not diminish the "Robin Hood"-feeling among (certain) file sharers.

Although ethical beliefs can only be influenced indirectly, public and private authorities could directly influence the risks of illegal downloading and the risk perception involved. While the risks of purchasing music legally are lower, it is vital the music industry reduces the technical risks to an absolute minimum and communicates on this subject effectively. Technical risks may be experienced more directly, because even small-scale downloaders could well end up with infected computers [75].

The music industry, in combating file sharing activities, has to be able to act against both file sharing networks and profit-driven networks. If they are not - due to regulatory problems in the country of origin for example [76] - the legal risks will shift and customers are thus pushed towards organized crime groups. If the legal risks were to be equally spread, however, organized crime groups would never be able to compete with file sharers when it comes to providing illegal music on the Internet.

\section{Conclusion}

The rise of the Internet combined with the plummeted costs of powerful home computers, may have set ajar Pandora's Box for law obeying citizens suddenly finding themselves in the possibility to copy, rip, upload and download music through the Internet for free. Today, with limited resources one can easily obtain his or her favourite music without ever having to visit a music store. This evolution has negative effects on $C D$ sales. Internet piracy is 
threatening illegal CD sales as well since the advent of file sharing networks influenced consumers' behaviour and altered the demand for CDs.

As a reaction to the threats of the digital era the music industry decided to distribute music online well knowing that consumers had to have alternatives for file sharing networks. A similar transformation of the business model is not that simple for organized music pirates. In the presence of file sharing networks, organized criminals are in hot water for they can no longer present themselves as a cheap or affordable alternative for the legal industry. Moreover, going online enhances the visibility of the criminals and although they will be perfectly able to by-pass law enforcement agencies for a while, they will still attract more attention to their activities than when they were operating black markets.

In order to survive the threats of the digital era, the music business has to go online. This might turn out to be a lot more difficult for organized music pirates than for the music industry. 


\section{References}

1. International Federation of the Phonographic Industry, "The Recording Industry: World Sales 2002', (London 2003), http://www.ifpi.org/content/library/worldsales2002.pdf, accessed 24 October 2007, p. 1.

2. G. Walsh, V.W. Mitchell, T. Frenzel and K.P. Wiedmann, "Internet-induced Changes in Consumer Music Procurement Behaviour: A German Perspective", 21 Marketing Intelligence and Planning (2003) pp. 305-317.

3. G. Walsh, V.W. Mitchell, T. Frenzel and K.P. Wiedmann, loc. cit.

4. International Federation of the Phonographic Industry, "IFPI Formal Submission to Australian Parliament House of Representatives Standing Committee on Legal and Constitutional Affairs", (Canberra, 1999), Australian Parliament House of Representatives,

http://www.aph.gov.au/House/committee/laca/copyrightenforcement/sub37ifpi.pdf, accessed 24 October 2007, p. 4.

5. Alliance against IP theft, "New Report Finds Organised Crime not Harmless Del Boys are Behind UK Fakes", (London 2003), http://www.allianceagainstiptheft.co.uk/archivearticle.html?id=34, accessed 6 June 2007.

6. J. Reno, "The Threat of Digital Theft", The Industry Standard (2000), http://seclists.org/politech/2001/Jan/0006.html, accessed 24 October 2007.

7. S.D. Porteous, “Organized Crime Impact Study Highlights. Public Works and Government of Canada" http://ww2.pssp.gc.ca/Publications/Policing/pdf/1998orgcrim_e.pdf, accessed 9 November 2007, p. 14-15.

8. See, for example, A. Zentner, "Measuring the Effect of Internet Piracy on Music Purchases", XLIX. Journal of Law and Economics (2006) pp. 63-90; R. Rob and J. Waldfogel, "Piracy on High C's: Music Downloading, Sales Displacement, and Social Welfare in a Sample of College Students", XLIX Journal of Law and Economics (2006) pp. 29-62; S.E. Siwek, "The True Cost of Sound Recording Piracy to the U.S. Economy"(Lewisville: Institute for Policy Innovation 2007), Policy Report 188, 14.

9. 149 PCs per 1,000 population worldwide in 2007 , see G. Shiffler, "Forecast: PC Installed Base, Worldwide, 2003-2011", GARTNER (Egham 2007), http://www.gartner.com/DisplayDocument?ref=g_search\&id=527124， accessed 16 January 2008.

10. At the end of 2005, 12 percent of households worldwide had a broadband connection and it is estimated that this figure will nearly double to 21 percent in 2010. See GARTNER, "Worldwide Consumer Broadband Penetration Sees Rapid Growth but Current Price Strategy Alone is Not Sustainable for Telecom Carriers", (Egham 2007), http://www.gartner.com/it/page.jsp?id=501276, accessed 16 January 2008.

11. Additional data was collected from the IFPI music reports (http://www.ifpi.co.uk/content/section_statistics/index.html).

12. The Big Five are BMG, Warner, Universal, Sony and EMI. After the merger of Sony and BMG, they are now called the Big Four.

13. J. Bishop, "Who are the Pirates? The Politics of Piracy, Poverty and Greed in a Globalized Music Market", 27 Popular Music and Society (2004) pp. 101-106, at 101.

14. J. Black, “Big Music's Broken Record", BusinessWeek, 13 February 2003, http://www.businessweek.com/technology/content/feb2003/tc20030213_9095_tc078.ht m, accessed 29 October 2007, p. 1. 
15. F. Oberholzer-Gee and K. Strumpf, "The Effect of File Sharing on Record Sales - An Empirical Analysis", 115 Journal of Political Economy (2007) pp. 1-42, at 39.

16. International Federation of the Phonographic Industry, "The Recording Industry 2006: Piracy Report Protecting Creativity in Music", (London 2006), http://www.ifpi.co.uk/content/library/piracy-report2006.pdf, accessed 24 October 2007, p. 4.

17. C.W.L. Hill, "Digital Piracy: Causes, Consequences, and Strategic Responses”, 24 Asian Pacific Journal of Management (2007) pp. 9-25, at 9.

18. International Federation of the Phonographic Industry, "The Recording Industry 2006: Piracy Report Protecting Creativity in Music", loc. cit., p. 4.

19. F.D. Sandulli, "CD Music Purchase Behaviour of P2P Users", 27 Technovation (2007) pp.325-334, at 326.

20. S. Liebowitz, "File Sharing: Creative Destruction or Just Plain Destruction?", 49 Journal of Law and Economics (2006) pp. 1-28, at 15.

21. See A.M. Levin, M. Conway, K. Rhee, "Money for Nothing and Hits for Free: The Ethics of Downloading Music from Peer-to-peer Web Sites", 12 Journal of Marketing Theory and Practice (2004) pp. 48-60; F. Oberholzer-Gee and K. Strumpf, loc. cit.

22. B. Andersen and M. Frenz, "The Impact of Music Downloads and P2P File-sharing on the Purchase of Music: a Study for Industry Canada. Research Report for Industry", (Canada 2007),

http://strategis.ic.gc.ca/epic/site/ippddppi.nsf/vwapj/IndustryCanadaPaperMay4_20 07_en.pdf/\$FILE/IndustryCanadaPaperMay4_2007_en.pdf>, accessed 9 November 2007, p. 33.

23. See, for example, A. Zentner, loc. cit.; D. Blackburn, "On-line Piracy and Recorded Music Sales", Working paper, (Harvard Business School 2004); N.J. Michel, "Internet File Sharing: The Evidence so Far and what it Means for the Future", 1790 Backgrounder (2004) pp. 1-6; M. Peitz and P. Waelbroeck, "The Effect of Internet Piracy on Music Sales: CrossSection Evidence", 1 Review of Economic Research on Copyright Issues (2004) pp. 71-79; R. Rob and J. Waldfogel, loc. cit.; G. Walsh, V.W. Mitchell, T. Frenzel and K.P. Wiedmann, loc. cit.

24. L. Marshall, "The Effects of Piracy upon the Music Industry: A Case Study of Bootlegging", 26 Media, Culture E Society (2004) pp. 163-81, at 164.

25. J. Menn, All the Rave: The rise and Fall of Shawn Fanning's Napster, (New York 2003) p. 1.

26. International Federation of the Phonographic Industry, "The Recording Industry 2006: Piracy Report Protecting Creativity in Music", loc. cit., p. 4.

27. G. Mariano, "Music Industry Burned by CD Piracy", ZDnet, (2002), http://news.zdnet.com/2100-9595_22-935243.html, accessed 9 January 2008.

28. International Federation of the Phonographic Industry, "The Recording Industry: World Sales 2005", (London 2005), http://www.ifpi.org/content/library/worldsales2004.pdf, accessed 24 October 2007, p. 1.

29. International Federation of the Phonographic Industry, "IFPI Formal Submission to Australian Parliament House of Representatives Standing Committee on Legal and Constitutional Affairs", Australian Parliament House of Representatives (Canberra 1999), http://www.aph.gov.au/House/committee/laca/copyrightenforcement/sub37ifpi.pdf accessed 24 October 2007, p. 7.

30. These are: (1) collaboration of more than two people, (2) each with own appointed tasks, (3) for a prolonged period of time, (4) using some form of discipline and control, (5) suspected of the commission of serious criminal offences, (6) operating on an international level, (7) using violence or other means suitable for intimidation, (8) using commercial or businesslike structures, (9) engaged in money laundering, (10) exerting 
influence on politics, the media, public administration, judicial authorities or the economy, and (11) determined by the pursuit of profit and/or power; Council of the European Union. 1997. Brussels: 6204/2/97, LIMITE Enfopol 35.

31. C.W.L. Hill, loc. cit., p. 15.

32. D.C. Smith, "Paragons, Pariahs and Pirates: A Spectrum-based Theory of Enterprise", 26 Crime and Delinquency (1980) pp. 358-386.

33. E.U. Savona and S. Adamoli, "The Impact of Organised Crime in Central and Eastern Europe". (Trento 1996), Transcrime Working Paper, p.7.

34. T. Vander Beken, "Risky Business: A Risk-Based Methodology to Measure Organized Crime", 41 Crime, Law and Social Change (2004) pp. 471-516, at 473.

35. D.C. Smith, loc. cit.

36. T. Vander Beken, Organised Crime and Vulnerability of Economic Sectors: The European Transport and Music Sector (Antwerp 2005).

37. M. Brunneli and B. Vettori, "European Music Sector", in T. Vander Beken, ed., Organised Crime and Vulnerability of Economic Sectors: The European Transport and Music Sector (Antwerp 2005) pp. 194-308, at 298.

38. M. Yar, "The Global Epidemic of Movie Piracy: Crime Wave or Social Construction?", 27 Media, Culture and Society (2005) pp. 677-696, at 679.

39. Union des Fabricants, "Counterfeiting and Organised Crime", (Paris 2003) Interpol, http://www.interpol.int/Public/FinancialCrime/IntellectualProperty/Publications/UD FCounterfeiting.pdf accessed 24 October 2007, p. 13.

40. M.F. Mertens, "Thieves in Cyberspace: Examining Music Piracy and Copyright Law Deficiencies in Russia as it Enters the Digital Age" (2005) ExpressO Preprint Series, Working Paper 663 , http://law.bepress.com/cgi/viewcontent.cgi?article=3196\&context=expresso, accessed 18 January 2008, p. 17-18.

41. T. Papadopoulos, "Pricing Strategy and Practice: Pricing and Pirate Market Formation", 13 Journal of Product and Brand Management (2004) pp. 56-63.

42. European Commission. 1998. "Green Paper Combating Counterfeiting and Piracy in the Single Market." Brussels: COM/98/0569.

43. J. Bishop, loc. cit., p. 104.

44. M.F. Mertens, loc. cit., p. 3.

45. T. Papadopoulos, loc. cit., p. 63.

46. M.F. Mertens, loc. cit., p. 17-18.

47. International Federation of the Phonographic Industry, "Music Piracy Report 2002" (London 2002) http://www.ifpi.org/content/library/piracy2002.pdf, accessed 24 October 2007, p. 3.

48. J. Kennedy, "Giving Music a Chance: Promoting New Markets and Fighting Piracy" (London 2006) http://www.ifpi.org/content/section_views/view016.html, accessed 24 October 2007.

49. Enigmax, "P2P File-sharing Ruins Physical Piracy Business" (2007) http://torrentfreak.com/p2p-file-sharing-ruins-physical-piracy-business/, accessed 24 October 2007.

50. C.K.M. Lam and B.C.Y. Tan, "The Internet Is Changing the Music Industry" 44 Communications of the ACM (2001) pp. 62-68, at 63.

51. M. McCandless, "The MP3 Revolution, The MP3 revolution, Intelligent Systems and Their Applications", 14 IEEE (1999) pp. 8-9, at 8.

52. P. Biddle, P. England, M. Peinado and B. Willman, "The Darknet and the Future of Content Distribution", in E. Becker, W. Bushe, D. Günnewig, N. Rump, eds., Digital Rights Managament: Technological, Economical, Legal and Political Aspects. (Washington DC 
2002) Proceedings ACM Workshop on Digital Rights Management Springer-Verlag, http://msl1.mit.edu/ESD10/docs/darknet5.pdf, accessed 10 October 2007, p. 5.

53. Organization for Economic Cooperation and Development, "Digital Broadband Content: Music" (Paris 2005) http://www.oecd.org/dataoecd/13/2/34995041.pdf, accessed 18 November 2007, p. 26.

54. International Federation of the Phonographic Industry, "Recording Industry Launches Fresh Wave of Actions Against Illegal File-sharing" (London 17 October 2006) http://www.ifpi.org/content/section_news/20061017.html, accessed 21 December 2007.

55. P. Biddle, P. England, M. Peinado and B. Willman, loc. cit., p. 15.

56. L. Graham, "The Legal Tortoise and the Technology Hare", 17 IEEE Software (2000) pp. 18-19, at 18.

57. P. Biddle, P. England, M. Peinado and B. Willman, loc. cit., p. 15.

58. J. Van Wijk, “Dealing with Piracy: Intellectual Asset Management in Music and Software", 20 European Management Journal (2002) pp. 689-698, at 689.

59. S. Bhattacharjee, R.D. Gopal, K. Lertwachara and J.R. Marsden, "Consumer Search and Retailer Strategies in the Presence of Online Music Sharing", 23 Journal of Management Information Systems (2006) pp. 129-59, at 131.

60. M. Styvén, "The Intangibility of Music in the Internet Age", 30 Popular Music and Society pp. 53-74, at 54 .

61. B. Andersen and M. Frenz, loc.cit., p. 33.

62. S. Liebowitz, "File Sharing: Creative Destruction or Just Plain Destruction?", 49 Journal of Law and Economics (2006) pp. 1-28, at 18.

63. See: A. Harmon, "Imagine; Tune in, Turn on, Pay up", The New York Times, 23 December 2001.

Available

at

http:/ /query.nytimes.com/gst/fullpage.html?res=9C0DE2DB1731F930A15751C1A9679

C8B63\&scp $=1 \&$ sq $=$ Imagine $\% 3 B+$ tune + in $\% 2 C+$ turn + on $\% 2 C+$ pay+up\&st $=$ nyt, accessed 26 October 2007; and J. Markoff, "New Venture to Seek Fees for Net Music", The New York Times

(2001)

http:/ /query.nytimes.com/gst/fullpage.html?res=9D04EEDE1E3FF930A35757C0A9679

$\mathrm{C} 8 \mathrm{~B} 63 \& \mathrm{scp}=1 \& \mathrm{sq}=\mathrm{New}+\mathrm{venture}+$ to + seek+fees+for+net+music\&st=nyt, accessed 26 October 2007.

64. Those reports can be accessed http://www.ifpi.org/content/section_statistics/index.html

65. M. Styvén, loc. cit., p. 54.

66. E.U. Savona and M. Mignone, "The Fox and the Hunters: How Technologies Change the Crime Race", 10 European Journal on Criminal policy and Research (2004) pp. 3-26, at 5.

67. R.D. Gopal, L.G. Sanders, S. Bhattacharjee, M. Agrawal, M. and S.C. Wagner, "A Behavioural Model of Digital Music Piracy", 14 Journal of Organizational Computing and Electronic Commerce (2004) pp. 89-105, at 95.

68. J. Chiou, C. Huang, H. Lee, "The Antecedents of Music Piracy Attitudes and Intentions", 57 Journal of Business Ethics (2005) pp.161-174, at 170.

69. R.D. Gopal, L.G. Sanders, S. Bhattacharjee, M. Agrawal, M. and S.C. Wagner, loc. cit., p. 102.

70. J. Chiou, C. Huang, H. Lee, loc. cit., p. 170-171.

71. S. Bhattacharjee, R.D. Gopal, K. Lertwachara and J.R. Marsden, loc. cit., p. 144.

72. R.D. Gopal, L.G. Sanders, S. Bhattacharjee, M. Agrawal, M. and S.C. Wagner, loc. cit., p. 102.

73. J. Bockstedt, R.J. Kauffman and F.J. Riggins, "The Move to Artist-led-on-line Music Distribution: A Theory-based Assessment and Prospects for Structural Changes in the Digital Market", 10 International Journal of Electronic Commerce (2006) pp. 7-38, at 13. 
74. International Federation of the Phonographic Industry, "Digital Music Report" (London 2006) http://www.ifpi.org/content/library/digital-music-report-2006.pdf, accessed 24 October 2007, p. 20.

75. G. Lawton, "Invasive Software, Who's Inside Your Computer", 35 Computer (2002) pp. 1518 , at 18 .

76. M.F. Mertens, loc. cit., p. 23-30. 